\title{
Research
}

\section{Responding to Globalization: Impacts of Certification on Colombian Small-Scale Coffee Growers}

\author{
Ximena Rueda ${ }^{1,2}$ and Eric F. Lambin ${ }^{1,3,4}$
}

\begin{abstract}
Eco-certification of food and other agricultural products has been promoted as a way of making markets work for sustainability. Certification programs offer a price premium to producers who invest in more sustainable practices. The literature on the impacts of certification has focused primarily on the economic benefits farmers perceive from participating in these schemes. These benefits, however, are often subject to price variability, offering only a partial explanation of why farmers join and stay in certification programs. We evaluated the potential of the Rainforest Alliance certification program to foster more resilient social-ecological systems in the face of globalization. Using the case of Santander, Colombia, and a pair-based comparison of 86 households to effectively produce a robust counterfactual, we showed that certification provides important environmental benefits, while improving the well-being of farmers and their communities. Furthermore, the study showed that price premiums are only one of many elements defining the success of certification, particularly important for motivating farmers to join, but less so to explain retention and upgrading. The case of Colombian coffee growers illustrates how the connections between local social-ecological systems and larger global forces can produce more sustainable livelihoods and land uses.
\end{abstract}

Key Words: coffee; Colombia; eco-certification; globalization; land change

\section{INTRODUCTION}

Eco-certification of food and other agricultural products has been promoted as a way of making markets work for sustainability. Certification programs that claim to promote environmental conservation and positive socioeconomic conditions offer a price premium and access to market shares to producers adopting certain practices. They bridge consumers' concerns for the way goods are produced with globalized commodity chains that depend on standardized quality attributes to reach global markets (Ponte and Gibbon 2005). Several certification programs exist today for global commodities such as timber, coffee, cocoa, and bananas with different claims to sustainability (Giovannucci and Ponte 2005, Dauvergne and Lister 2012). Four certification programs include the coffee sector: Rainforest Alliance, UTZ, Organic, and Fair Trade. They consist of a code to which farmers must adhere, a third-party, i.e., independent, audit to verify compliance, and the right to use a seal on the packaged product sold to consumers. We discuss elsewhere verification programs and two-party, i.e., industry-led, codes (Rueda and Lambin 2013).

The literature on the impacts of certification at the local level has focused primarily on the economic benefits farmers perceive from participating in these schemes (Blackman and Rivera 2010, STAP 2010, Beuchelt and Zeller 2011). These benefits, however, are often subject to price variability (Rueda and Lambin 2013) offering only a partial explanation of why farmers join and stay in certification programs. Beyond the direct payments, certification may provide other socioeconomic benefits, not intended in their design, which remain poorly understood (Giovannucci and Ponte 2005, Ha and Shively 2008). The need to comply with a strict set of criteria, coupled with a more explicit exposure to market trends and preferences, can promote institutional and individual changes of benefit to farmers. Adopting quality and environmental standards improves the ability of smallholders to build local networks that foster knowledge circulation and bring resources to local actors (Perez-Aleman 2012). Certification can also generate spillover effects on the adjacent farms and communities through technological diffusion and improved transparency and traceability in the market. As farmers upgrade production they can be better equipped to face evolving market demands.

A byproduct of globalization, certification holds the potential to transform the nature of the connections between local places and global forces (Adger et al. 2009). Scholars have attempted to evaluate the impacts of globalization on smallholder agriculture (Bardhan 2006, McCullough et al. 2008). In general, trade liberalization has resulted in the geographical specialization of agriculture. The production of staple goods by small farmers has decreased globally (Zimmerer 2007). Households have also found alternative sources of income, on and off the farm (Reardon et al. 2007). In some places, farmers have turned to the diversity of the agroecological systems to supply goods for local and international markets (King 2007, Lybbert et al. 2011), whereas others are deepening their engagement with high value, export-oriented commodities (McCullough et al. 2008). It has been argued that globalization has exacerbated smallholders' exposure to market volatility and economic cycles (O'Brien and Leichenko 2000, Adger et

\footnotetext{
${ }^{1}$ Department of Environmental Earth System Science, School of Earth Sciences, Stanford University, ${ }^{2}$ School of Management, Universidad de los Andes, ${ }^{3}$ Woods Institute for the Environment, Stanford University, ${ }^{4}$ Georges Lemaître Centre for Earth and Climate Research, Earth and Life Institute, Université catholique de Louvain
} 
al. 2009). Also, in buyer-driven chains such as coffee, opportunities for smallholders to join and upgrade might be limited (Lee et al. 2012).

Concerns have also been raised over the environmental impacts of agricultural liberalization, particularly the loss of biological diversity resulting from simplified agricultural systems (Zimmerer 2010). Long-term and comparative studies have demonstrated the complex interplay between households, land use, and biodiversity, and the dynamic and innovative role smallholders play in maintaining ecological diversity (Brookfield et al. 2002, Perfecto and Vandermeer 2008). The transition from swidden to commercial agriculture often leads to negative environmental impacts (van Vliet et al. 2012). The effects of globalization are not unidirectional, however, and in specific instances, market liberalization has promoted increased agrobiodiversity conservation and use (Aide and Grau 2004, Benin et al. 2005).

The environmental benefits of certification have received some attention (Kaplinsky 2004, van Kuijk et al. 2009, Blackman and Naranjo 2010, Tejeda-Cruz et al. 2010), albeit mostly through comparisons of biodiversity in an array of production systems not necessarily tied to specific certification schemes (Tangley 1996, Perfecto et al. 2003, Mas and Dietsch 2004). By encouraging more diverse and complex agroecological systems, certification can contribute to the enhancement of habitat connectivity while protecting valuable ecosystem services. Certification schemes hold the potential to attenuate the biophysical simplification often associated with globalization (Young et al. 2006), enhancing the resilience of the social-ecological system (Folke 2006, Zimmerer 2010).

The appeal of certification as a market mechanism that efficiently allocates resources based on a social price tag to sustainability has been highly contested. First, no matter how green, eco-consumerism is still part of a market economy that relies on the consumption of ever-growing amounts of resources (Adams 2001). Challenges also refer to issues of governance and asymmetric distribution of power among actors in the global value chains in which these green commodities are exchanged (Daviron and Vagneron 2011). Furthermore, sustainability standards might erect barriers to entrance for smallholders, the main suppliers for many of the green commodities, furthering inequality not only across borders but domestically (Gómez et al. 2011).

Retailers and manufacturers, the leading actors in many of the agrofood supply chains, are becoming powerful forces of environmental governance, both setting the standards and driving environmental change (Dauvergne and Lister 2012). Governments in producing and consuming countries and multilateral donors have embraced certification as one of their methods to reach the global poor and produce large-scale change in rural development (UNEP 2007, Andersson et al. 2010). As certification expands geographically and over a growing number of commodities, understanding its potential to transform livelihoods and landscapes becomes more urgent.

Our objective was to evaluate the potential of certification to foster more responsive social-ecological systems in the face of globalization. Using the case of Santander, a coffee growing region in Colombia, we tested whether: (1) certification schemes provide significant nonmonetary benefits to farmers, in addition to a price premium, that strengthen their socioeconomic responsiveness to market changes; (2) certification schemes foster the conservation of ecosystems; and (3) premiums are the main incentives for farmers to join certification and to remain in the system.

\section{STUDY AREA AND EARLY HISTORY OF CERTIFICATION}

We focused on the implementation of the Rainforest Alliance (RFA) certification program in Santander, a province in the eastern Andes of Colombia. The Rainforest Alliance is an environmental NGO that uses market-based mechanisms to preserve biodiversity while enhancing people's livelihood, linking business to environmentally-minded consumers through the RFA-certified ${ }^{\mathrm{TM}}$ seal. The seal was first used for timber, "Smartwood" in 1989, and later expanded to agriculture, i.e., bananas in 1992 and coffee in 1996. In 2004, coffee certification went mainstream with Procter and Gamble and Kraft foods launching RFA-certified products for particular markets (RFA 2012). Today, more than 300,000 metric tons of RFA-certified coffee are produced annually around the world; about half of them are traded internationally (RFA 2011), representing close to $2 \%$ of the global market (USDA 2011).

The RFA certification is granted to farms that comply with a comprehensive standard including environmental, social, and economic criteria. To manage the certification program in the field and provide technical guidance, the Rainforest Alliance with a group of environmental NGOs, created a network of organizations, known as the Sustainable Agriculture Network (SAN). The SAN designed the standard, which includes 90 criteria to be verified at the farm level and 16 criteria at the group level, for farms applying for a collective certification (RFA 2012). The guiding principles of the SAN standard refer to the implementation of a management system for the farm, ecosystem conservation, wildlife protection, water conservation, working conditions, occupational health, community relations, integrated crop management, soil conservation, and integrated waste management. The SAN standard is designed to maintain the farm's productivity. Contrary to the organic certification, there is no restriction to the use of synthetic 
fertilizers, and most low-toxicity pesticides are permitted if used under an integrated management strategy. Coffee bearing the RFA-certified seal has historically commanded the largest premiums among certification programs (Rueda and Lambin 2013).

In 2002, Colombia embarked in a "Cafés Especiales" strategy to create greater revenue for farmers by adding more value at origin, and entering new market segments that would increase the recognition of the origin of the coffee (Reina et al. 2008). The strategy was carried out by the Colombian Coffee Growers Federation (FNC for its acronym in Spanish) to which the vast majority of farmers belong. The organization collects an export tax and receives additional funding from the Colombian government and other donors. These resources pay for, among others, a nation-wide extension service. FNC also purchases and exports $30 \%$ of all Colombian coffee. The strategy was a success. By 2010, more than 25\% of farmers and over $30 \%$ of Colombian coffee were under certification and verification programs. The exports of value added coffee had reached 1 MM bags, about half of all FNC exports (Rueda and Lambin 2013).

Santander was one of the first departments to adopt certification programs. Because of a nine-month dry season, most of the coffee cultivated in Santander grows under shade. This favorable condition reduces the need for external outputs and incorporates some tree species into the landscape, thus complying with the SAN standards was an attractive option for local coffee growers. Santander has been a coffeeproducing region since the 19th century (Parsons 1949, Bejarano 1987). It was one of the main players in the early history of coffee in Colombia, based on a production system of large haciendas. Its importance declined through the 20th century because the western Andes were opened for agricultural production (Parsons 1949), and the large haciendas became less profitable. In recent times, Santander has maintained a modest but highly productive coffee area of approximately 45,000 hectares, about $5 \%$ of the total area planted in the country (FNC 2011). Today 32,700 families in the region grow coffee, $97 \%$ of which are smallholders with less than 5 hectares. Almost 7000 farmers, covering about 17,000 hectares of coffee fields, are involved in sustainability programs. These farmers account for more than $20 \%$ of all coffee growers in the region, representing close to $40 \%$ of Santander's area planted in coffee (FNC 2010).

In 2002 the Rainforest Alliance officers visited local farms and helped formalize a sales agreement with one of the largest coffee roasters. FNC's extension service, together with farmers and auditors, worked to translate the SAN protocol into applicable actions in the local context. The first 14 farms obtained the certification in 2002. By 2004, more than 110 farms had been incorporated into the RFA certification program, and by 2010 this number was well above 1000 farms.
Other certification and verification programs have grown along with the RFA (Rueda and Lambin 2013), but this one has been the backbone of the sustainability efforts in Santander.

To secure the supply of RFA-certified coffee from Santander, FNC targeted first the larger farm owners who could reliably provide a large volume of certified coffee to the market. It also tapped into the interest of those who were already participating in the organic certification and were looking for ways to further add value to their product. The local extension service supported the adoption of the SAN standards among all farmers who would be willing and able to comply with certification requirements, regardless of size or tenure system. FNC helped farmers upgrade their infrastructure through access to credit and by offering matching funds from their own resources and national and international donors. The promise of a price premium elicited many farmers to participate in the program. Records at FNC indicate that the premium paid for RFA-certified coffee in 2002 reached the equivalent of 17 cents/lb for green coffee, although the international price for Colombian coffee was only 40 cents/lb at that time. The premium thus represented an additional income of $40 \%$. The economic incentive was substantially reduced over time, as the global supply of sustainable coffee grew and international prices for Arabica coffee increased. At the time of this study, the premium represented an additional income of less than $3 \%$ above the standard price.

The trading branch of the FNC, together with the network of purchasing cooperatives, developed a traceability system to comply with the requirements of the certification program. Cooperatives offered a transparent system to trace coffee purchases to farmers, and FNC ensured complete separation of the certified coffee from the purchasing station to its delivery to the clients.

\section{METHODS}

Our study relied on a combination of quantitative and qualitative methods based on interviews with key informants and a household survey to provide a comprehensive understanding of certification's outcomes on livelihoods and ecosystems. The household survey used a pair-matched casecontrol method, frequently employed in epidemiological (Jewell 2004) and ecological studies (Benayas et al. 2009) to compare pairs of like individuals whose only observable difference was whether or not they participated in certification schemes. This method produces a robust counterfactual to evaluate the impacts of certification, overcoming one of the most often-cited problems of this kind of evaluation (Blackman and Rivera 2010). Other available methods for evaluating impacts include statistical approaches, such as propensity score matching (PSM; Rosenbaum and Rubin 1983) and econometric modeling, such as the Heckman twostep correction method (Winship and Mare 1992). We did not 
use PSM for lack of ancillary information on both the treatment and the control groups. Strong assumptions on the nature of the selection process, that is unknown to the researchers, prevented us from using the Heckman two-step correction method to address the issue of selection bias (Sobel 2005, Guo and Fraser 2010). Outcomes for the paired samples were compared using the Wilcoxon-signed rank test, which tests whether there are systematic differences within pairs, and the McNemar Chi's test for marginal homogeneity, which tests differences between paired proportions for discrete variables. Individuals were selected from five municipalities, San Gil, Socorro, Pinchote, Curití, and Valle del San José. As of December 2010, there were 201 certified farms in the region with a GPS point tied to them. We randomly selected a sample of 43 certified farmers, $21 \%$ of the universe. For the noncertified counterparts, we relied on the expert judgment of local agricultural extension agents to choose the closest noncertified farm of similar size from the neighbors of each selected certified farm. This sampling method ensured that, based on the information at hand a priori, pairs of farms shared similar biophysical and accessibility attributes. A total of 86 farms were interviewed (43 pairs) during the months of August to October of 2011, ranging in size from 0.8 to 91 hectares. For the most part, pairs were obtained from adjacent neighbors. For large farms, identifying a suitable pair sometimes required selecting farms from neighboring municipalities.

In the survey, we included a set of variables to check a posteriori whether our sample selection method had effectively controlled for possible selection bias, a challenge of such evaluations (Blackman and Rivera 2010). These refer to access to markets, i.e., for coffee and credit, engagement in local networks, altitude, and household socioeconomic characteristics, i.e. age of the household head, size of the household, level of education, land tenure, importance of coffee for the household economy, and off-farm opportunities.

The survey identified current agronomic and environmental practices that pertain to land use, following the 2010 version of the SAN standard (SAN 2010): record keeping, ecosystem conservation, water use and discharge, pests, soil, and waste management. A comparison between the two groups allowed us to define the degree to which joining certification was associated with changes in farmers' practices. Practices were verified through farm visits, by walking through the plantation and processing facilities. The survey also asked certified farmers about their practices before joining certification. Land histories, reconstructed through the interviews and farm visits, helped us detect changes in land use, including both expansion and intensification in coffee cultivation, and to compare land use trajectories between certified and noncertified farmers since the onset of the certification program in the early 2000 s. Records from certified farmers were consulted for clarification but were not used as the main method of verification because its use among noncertified farmers is scant.

The questionnaire also included an evaluation of: (1) the direct economic benefit received from certification, i.e., premiums over noncertified coffee in the previous harvest year; (2) the most significant benefits they perceived from joining certification, material or otherwise; and (3) the outlook for the future. Certified farmers were asked about their likelihood of continuing in the program under the current market conditions and their expectations for the next generation's involvement in farming.

An analysis of the long-term economic benefits derived from certification was beyond the scope of this study. Coffee is a semiperennial crop with cycles varying from 9 to 20 years. Any coffee farm has a patchwork of lots at different stages of development and with varying yields. Coffee prices are also subject to volatility. An economic analysis would require a longitudinal study of coffee farms in and out of certification through several production and price cycles. Although the RFA certification program claims that it enhances the economic sustainability of the farm, no farm-level criterion specifically verifies increases in the farm's productivity.

\section{RESULTS}

\section{Testing for a possible selection bias}

Certified and noncertified farms were located in close proximity and at similar altitudes (Table 1). Certified and noncertified households were alike in terms of age of the household head, number of people living in the household, and education level attained by the head of household (Table 1). Land tenure among farmers in the study was dominated by legal ownership, $93 \%$ of certified and $77 \%$ of noncertified, and not significantly different between the two groups (Table 2). The majority of both certified and noncertified farmers had other members of the household supplementing the household income, most of them from nonfarm sources, with no significant difference between the two groups (Table 2). The only significant difference in household characteristics was the role of coffee in the household's economy. Many more certified households declared that coffee was their main activity compared to noncertified ones. This was manifested also in a larger proportion of their farm devoted to coffee (Tables 1 and 2).

In terms of access to markets, farmers in the study area had access to a variety of buyers in nearby towns, including FNC's cooperative and private traders. All farmers interviewed lived by a rural road and had access to transportation to take their coffee into town. More certified farmers chose to sell to the cooperative than noncertified ones, who prefer to sell to local traders (Table 2). The cooperative is the only buyer that pays a premium for certified coffee. Price was by far the main reason 
Table 1. Difference in practices between certified and noncertified farms: continuous variables $(\mathrm{n}=86)$.

\begin{tabular}{|c|c|c|c|c|}
\hline & Certified & Noncertified & Wilcoxon test & $\mathrm{p}$ - value \\
\hline & \multicolumn{2}{|c|}{ Median values } & & \\
\hline \multicolumn{5}{|l|}{ Biophysical characteristics } \\
\hline Altitude & 1648 & 1645 & 484 & 0.689 \\
\hline \multicolumn{5}{|l|}{ Socioeconomic characteristics } \\
\hline Age of household's head & 53 & 55 & 505.5 & 0.503 \\
\hline Number of people in the household & 4 & 4 & 267.5 & 0.203 \\
\hline Number of years of education of the head of household & 5 & 5 & 240.5 & 0.891 \\
\hline Highest number of years of education of household members & 13 & 11 & 394.5 & $0.042 *$ \\
\hline \multicolumn{5}{|l|}{ Ecosystem conservation } \\
\hline Number of tree species per hectare & 9 & 6 & 626.5 & $0.000^{*}$ \\
\hline \multicolumn{5}{|l|}{ Land expansion } \\
\hline Number of hectares of land devoted to coffee & 4.5 & 4 & 603.5 & $0.003 *$ \\
\hline Number of hectares expanded since certification/last 5 years & 1 & 1 & 403.5 & 0.271 \\
\hline
\end{tabular}

behind their preference for a specific trader (Fig. 1). Certified farmers mentioned loyalty to the cooperative and commitment to deliver the amount specified at the beginning of the year as other reasons for their preference. Noncertified farmers mentioned being treated fairly, i.e., accurate weight, as an important reason for choosing among traders and complained that the cooperative was very demanding in terms of quality. Additional services such as credit or availability of fertilizers did not have much of an impact on their choice (Fig. 1).

Fig. 1. Main reasons certified and noncertified farmers gave for their choice of buyer (cooperative or trader; $n=86$ ).

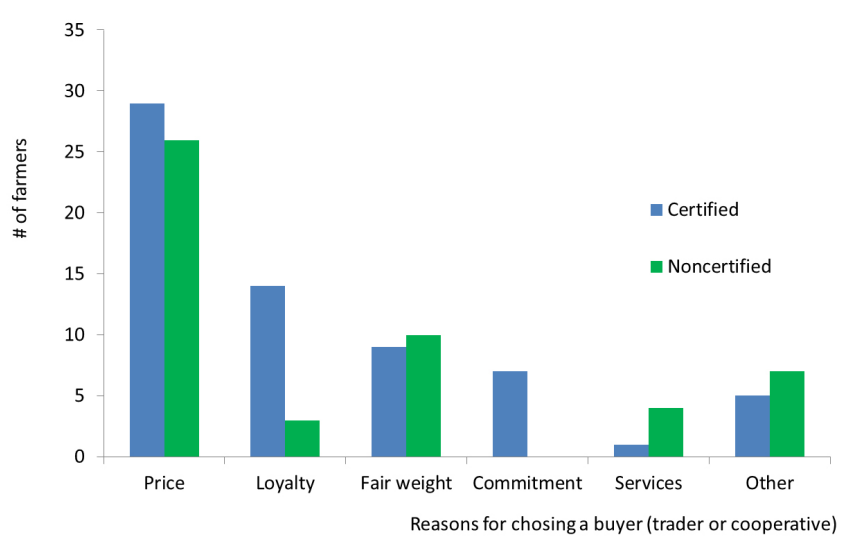

Credit was readily available for all farmers through Banco Agrario, the government-sponsored financial institution for agricultural development, commercial banks, and credit unions. Investments in certification, renovation, and expansion had all relied on credit to some extent, without significant differences between the two groups. Access to credit, markets, technology, inputs, and other services had been facilitated by FNC, reaching both certified and noncertified farmers alike.

\section{Economic benefits of certification}

Out of 43 certified farmers, 29 declared to have received a premium for their coffee (Table 3 ). The average premium received was Col\$ 18,333 , about $2 \%$ above the price paid for standard, noncertified coffee for that harvesting season (FNC 2011). Two-thirds of the certified farmers sold their coffee as such whereas the rest sold it as standard coffee to traders who operate outside of the certified-coffee circuit. None of the noncertified farmers received any additional payment for their coffee.

\section{Environmental benefits of certification}

Certified farmers had adopted significantly more environmentally friendly practices than noncertified farmers, such as tree diversity, watershed protection through fencing and reforestation, and infrastructure for water-use efficiency and wastewater management (Tables 1 and 2). These practices significantly increased after farmers joined the certification program (Table 4).

Certified farmers had adopted integrated management strategies to control the two most prevalent phytosanitary problems they face, i.e., infestation by the berry borer (Hypothenemus hampei) and leaf rust (Hemileia vastratix), in significantly greater numbers than the noncertified ones. Certified farmers collected ripe and over-ripe fruits from the trees and floor, an effective practice to control the berry borer (McMichael 2007), at a higher rate than noncertified farmers (Table 2). Adoption of this practice increased after 
Table 2. Difference in practices between certified and noncertified farms: dichotomous variables $(n=86)$.

\begin{tabular}{|c|c|c|c|c|}
\hline & Certified & Noncertified & $\begin{array}{l}\text { McNemar's Chi- } \\
\text { square test }\end{array}$ & $\mathrm{p}$ - value \\
\hline & \multicolumn{2}{|c|}{ Median values } & & \\
\hline \multicolumn{5}{|l|}{ Socioeconomic characteristics } \\
\hline Number of farmers with land title & 39 & 33 & 3.125 & 0.077 \\
\hline Number of farmers for whom coffee is the main activity & 38 & 28 & 5.786 & $0.016^{*}$ \\
\hline $\begin{array}{l}\text { Number of households that have other members contributing to } \\
\text { household income }\end{array}$ & 25 & 24 & 0.191 & 0.663 \\
\hline Number of households that have off-farm income & 25 & 21 & 0.762 & 0.383 \\
\hline \multicolumn{5}{|l|}{ Access to markets, credit, and networks } \\
\hline Number of households that have access to information on prices & 36 & 35 & 0.000 & 1 \\
\hline Number of households who sell to the cooperative & 41 & 22 & 17.053 & $0.000^{*}$ \\
\hline Number of households who sell to traders & 28 & 39 & 7.692 & 0.006 \\
\hline Number of household who had access to credit for renovation & 30 & 20 & 3.375 & 0.066 \\
\hline Number of household who had access to credit for coffee expansion & 12 & 15 & 0.191 & 0.663 \\
\hline Number of farmers who belong to organizations besides FNC & 34 & 13 & 14.815 & $0.000^{*}$ \\
\hline \multicolumn{5}{|l|}{ Ecosystem conservation } \\
\hline Number of farmers who planted trees outside the coffee plots & 32 & 20 & 6.722 & $0.010^{*}$ \\
\hline $\begin{array}{l}\text { Number of farmers who protect water sources through fencing and } \\
\text { reforestation }\end{array}$ & 27 & 18 & 5.818 & $0.016^{*}$ \\
\hline \multicolumn{5}{|l|}{ Water conservation and water discharge } \\
\hline Number of farmers who use water-saving technologies for depulping & 32 & 17 & 11.529 & $0.001 *$ \\
\hline Number of farmers who have grease traps in the kitchen & 42 & 11 & 27.273 & $0.000^{*}$ \\
\hline Number of farmers who throw waste water to the field & 2 & 10 & 4.900 & $0.027^{*}$ \\
\hline \multicolumn{5}{|l|}{ Integrated crop management } \\
\hline Number of farmers who collect ripe and over-ripe fruits & 39 & 26 & 8.471 & $0.003^{*}$ \\
\hline Number of farmers who use biological control (Beauveria bassiana) & 8 & 4 & 1.125 & 0.289 \\
\hline Number of farmers who use chlorpyrifos & 10 & 14 & 0.750 & 0.387 \\
\hline Number of farmers who have adopted the rust-resistant varieties & 42 & 29 & 9.6 & $0.002^{*}$ \\
\hline \multicolumn{5}{|l|}{ Soil management and conservation } \\
\hline Number of farmers who use organic fertilizer & 37 & 28 & 3.765 & 0.052 \\
\hline Number of farmers who use synthetic fertilizer & 37 & 41 & 1.500 & $0.221^{*}$ \\
\hline Number of farmers who use soil analysis & 10 & 4 & 4.167 & $0.041^{*}$ \\
\hline Number of farmers who use glyphosate & 17 & 16 & 0.563 & 0.453 \\
\hline \multicolumn{5}{|l|}{ Integrated waste management } \\
\hline Number of households that collect trash from the field & 41 & 13 & 26.036 & $0.000^{*}$ \\
\hline Number of households that recycle & 41 & 14 & 23.310 & $0.000^{*}$ \\
\hline Number of households that burn or bury trash & 2 & 27 & 17.926 & $0.000^{*}$ \\
\hline \multicolumn{5}{|l|}{ Record keeping } \\
\hline Number of households that keep records & 43 & 13 & 32.237 & $0.000^{*}$ \\
\hline \multicolumn{5}{|l|}{ Land intensification } \\
\hline $\begin{array}{l}\text { Number of farmers who renovated the coffee plantation by new planting } \\
\text { since certification/last } 5 \text { years }\end{array}$ & 39 & 33 & 2.083 & 0.149 \\
\hline $\begin{array}{l}\text { Number of farmers who renovated the coffee plantation by stumping } \\
\text { since certification/last } 5 \text { years }\end{array}$ & 26 & 14 & 4.654 & 0.031 \\
\hline
\end{tabular}


Table 3. Price of Rainforest Alliance (RFA) certified coffee for the 2010-2011 harvest season, Santander, Colombia.

\begin{tabular}{lc}
\hline \hline & $\begin{array}{c}\text { Col\$ per 125 kg of } \\
\text { parchment coffee }\end{array}$ \\
\hline Average price paid to farmers during the 2010-2011 harvest & $\$ 955,477$ \\
Average premium paid to farmers in the study for RFA-certified coffee & $\$ 18,333$ \\
Premium as a \% of total price & $2 \%$ \\
Number of farmers in the study who sold RFA-certified coffee & 29 \\
Percentage of RFA-certified farmers who sold certified coffee & $67 \%$ \\
\hline
\end{tabular}

certification (Table 4). The use of biological controls was not significantly different between the two groups, neither was the use of chlorpyrifos, an insecticide (Table 2).

All but one of the certified farmers had partially or fully adopted the rust-resistant varieties of coffee. Susceptible varieties were still present in 14 noncertified farms and in one certified farm. The use of fungicides was negligible for both types of farmers (Table 2).

Both certified and noncertified farmers applied organic and synthetic fertilizers and used synthetic herbicides, glyphosate. Differences between the two groups with regard to these practices were not significant. There was a significant difference in the use of soil analysis to guide the application of fertilizer: $23 \%$ of the certified farmers used it, whereas only $9 \%$ of the noncertified did. Certified farmers significantly increased the use of soil analysis once they joined certification (Table 4).

All waste management activities were significantly different between certified and noncertified farmers: 95\% of the certified farmers in the area collected and separated their trash, recycling, and disposing of the remaining trash in the closest town. Only $30 \%$ of the noncertified farmers collected the trash from the field, $32 \%$ recycled cans, plastics and glass, and $63 \%$ burned or buried their trash (Table 2). Before certification, certified farmers did not engage in any of the required practices, leaving plastics and cans in the fields, burning and burying trash, and mixing recyclable and nonrecyclable materials (Table 4).

\section{Impacts of certification on land expansion and intensification}

Both certified and noncertified farmers have expanded the land devoted to coffee in the last five years. For all certified farms, the total area of land under coffee cultivation grew from 267.3 ha to 394.2 ha, a $47 \%$ increase. Noncertified farms increased the total area devoted to coffee from 185.9 ha to 257.4 ha, a $38 \%$ increase. On a pair-case basis, the increase was not significantly different between the two groups (Table 1).

The source of land used to expand coffee was roughly the same for certified and noncertified farmers (Fig. 2). The SAN standard prohibits farmers from clearing natural vegetation to expand agriculture (SAN 2010). Three noncertified farmers declared to have cleared secondary vegetation whereas none of the certified ones did.

Fig. 2. Land cover replaced by certified and noncertified farmers to expand coffee cultivation.

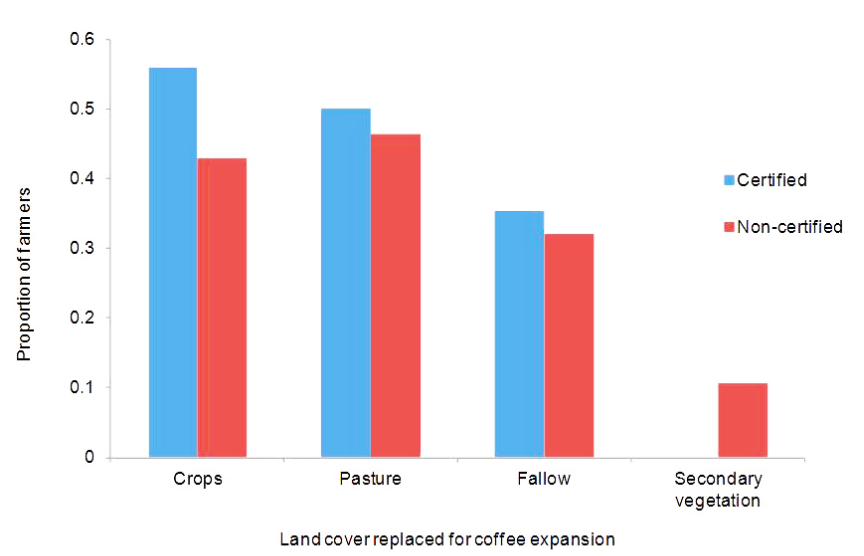

Most farmers, certified and noncertified alike, had actively engaged in renovation of their coffee farms, either by stumping or by replacing old trees. Renovation maintains and may enhance land productivity as older trees are replaced by new ones. Differences between the two groups were significant for renovation by stumping but not by replacement (Table 2).

\section{Impacts of certification on farmers' well-being}

Children of certified farmers had significantly higher educational levels that those of noncertified ones (Table 1). The median educational achievement of children of certified farmers was two years higher than the one for noncertified farmers. Certified farmers also joined associations and informal groups significantly more frequently than noncertified ones (Table 2).

The promise of a premium for their coffee was the reason why $60 \%$ of certified farmers decided to join such a program (Fig. 3). Organization of the household, which usually comprises upgrading kitchens, bathrooms, and bedrooms, dedicating a 
Table 4. Difference in practices for certified farms before and after joining certification $(n=43)$

\begin{tabular}{|c|c|c|c|c|}
\hline & Current & $\begin{array}{c}\text { Before } \\
\text { certification }\end{array}$ & $\begin{array}{c}\text { Wilcoxon/McNemar } \\
\text { test } \\
\end{array}$ & $\mathrm{p}$ - value \\
\hline & \multicolumn{2}{|c|}{ Median values } & & \\
\hline \multicolumn{5}{|l|}{ Ecosystem conservation } \\
\hline Number of tree species per hectare & 9 & 5 & 415.5 & $0.000 *$ \\
\hline Number of farmers who planted trees outside the coffee plots & 32 & 10 & 20.045 & $0.000 *$ \\
\hline $\begin{array}{l}\text { Number of farmers who protect water sources through fencing } \\
\text { and reforestation }{ }^{\dagger}\end{array}$ & 31 & 23 & 6.125 & $0.013^{*}$ \\
\hline \multicolumn{5}{|l|}{ Water conservation and water discharge } \\
\hline $\begin{array}{l}\text { Number of farmers who use water-saving technologies for } \\
\text { depulping }\end{array}$ & 32 & 18 & 12.071 & $0.001 *$ \\
\hline Number of farmers who have grease traps in the kitchen & 42 & 8 & 30.250 & $0.000 *$ \\
\hline $\begin{array}{l}\text { Number of farmers who throw waste water to the field } \\
\text { Integrated crop management }\end{array}$ & 2 & 28 & 22.321 & $0.000^{*}$ \\
\hline Number of farmers who collect ripe and over-ripe fruits & 39 & 21 & 14.450 & $0.001 *$ \\
\hline \multicolumn{5}{|l|}{ Soil management and conservation } \\
\hline Number of farmers who use soil analysis & 10 & 1 & 5.818 & $0.016^{*}$ \\
\hline \multicolumn{5}{|l|}{ Integrated waste management } \\
\hline Number of farmers who collect trash from the field & 41 & 6 & 33.029 & $0.000 *$ \\
\hline Number of farmers who recycle & 41 & 2 & 37.026 & $0.000 *$ \\
\hline Number of farmers who burn or bury trash & 2 & 40 & 36.026 & $0.000 *$ \\
\hline
\end{tabular}

* Significant at the 0.05 level.

${ }^{\dagger} \mathrm{n}=33$ pairs: Not all farms have water sources in or adjacent to the property. The comparison includes only those for whom the question is relevant.

Wilcoxon test applies for continuous variables and McNemar for dichotomous ones.

specific place for storage of tools and pesticides, and excluding animals from the house, came second. Environmental concerns, mainly referring to watershed protection, trash collection, recycling, and correct handling of pesticides were also a prominent reason. Ninety-six percent of the farmers in the survey attributed their participation in certification to at least one of these benefits. To a lesser degree, farmers mentioned managerial skills, improved technical assistance, and increased productivity as additional reasons for entering certification. A small number of them mentioned higher productivity and better quality as well as other motivations, such as meeting other farmers, improving access to resources for renovation, improved access to credit, a leadership role to play, and the existence of a market for certified products.

Concerning their reasons to remain in the program in the long run, farmers placed organization of household activities and awareness of environmental conservation highest on the list (Fig. 4). Managerial skills, access to technical assistance, and higher productivity were important benefits, but new motivations became prominent in farmers' assessment of certification: learning better farming practices, developing stronger family and community ties, improving treatment to workers and their overall quality of life, and playing a leadership/model role in their community.

\section{DISCUSSION}

The pair-matched, case-control methodology used in this study allowed for the successful controlling of possible confounding factors such as access to markets for coffee and credit, engagement in local networks, education, wealth, and biophysical characteristics. The only exception is the role of coffee in the household economy, as more certified households devoted larger portions of their land to coffee, and consequently declared that coffee was their main activity, compared to noncertified ones (Tables 1 and 2). Lack of longitudinal data prevents us from determining whether being a specialized coffee grower prompts a farmer to become certified, or whether certification leads to greater intensification and thus dependence on coffee. In either case, these variables reinforce each other to produce important socioeconomic and ecological benefits at the local and regional levels. 
Fig. 3. Certified farmers' main reasons for joining certification $(n=43)$.

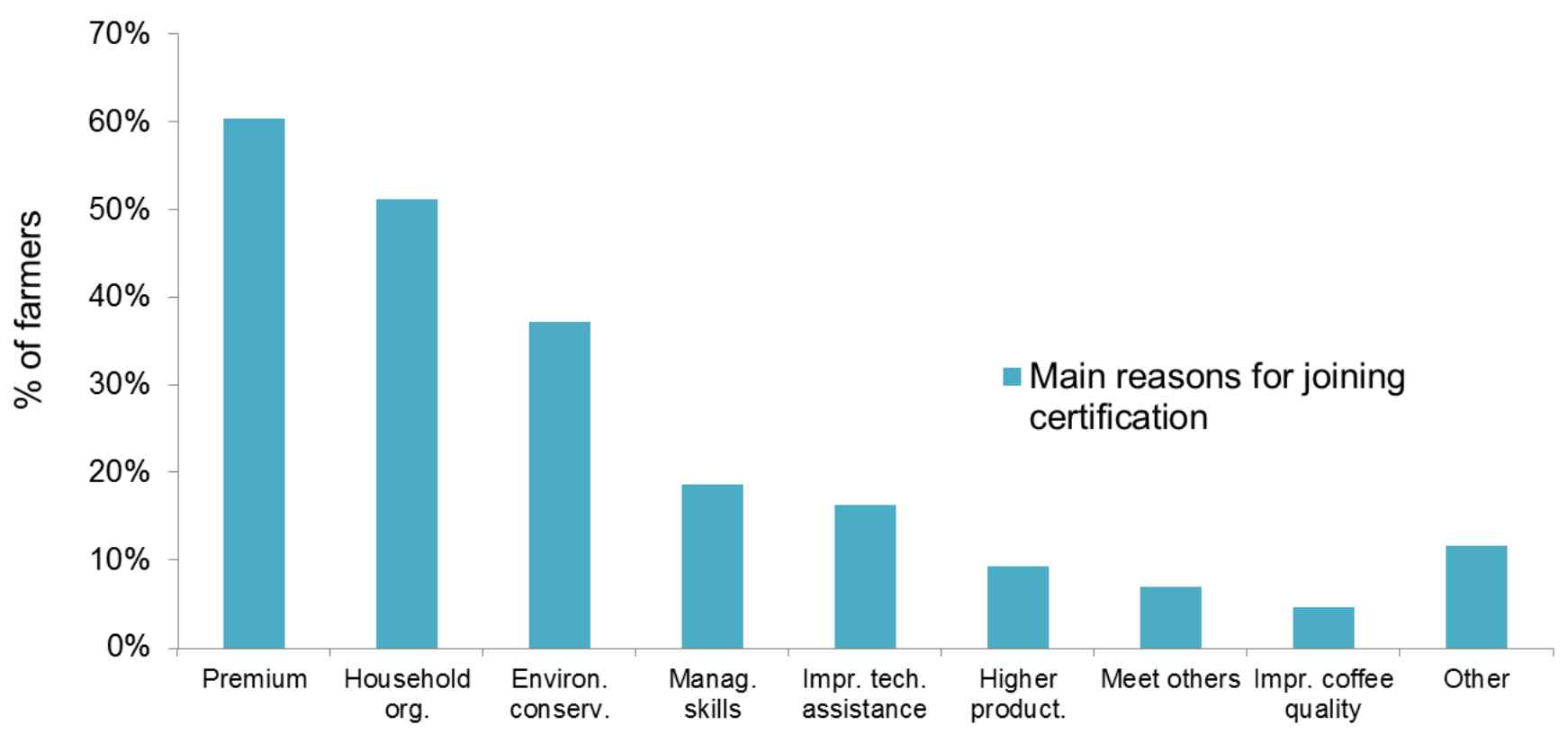

Certification programs are transforming the ways in which local places connect to global markets. Driven by external demand, coffee growers in Santander are introducing changes in the production systems that benefit both their farm operation and the natural environment. This study showed that certified growers added value to the farm and reduced their exposure to price volatility (Rueda and Lambin 2013), as well as became better able to respond to new market trends by investing in their human, social, and natural capital. Benefits extend beyond mere economic rewards.

The need to comply with a strict set of criteria, coupled with a broader exposure to market trends and preferences, is promoting a more responsive institutional network of technical assistants and farmers, groups that foster knowledge circulation and bring resources to local actors, supporting recent findings in other contexts (Perez-Aleman 2012). Certified farmers have gained access to knowledge and information that is transferred vertically, horizontally, and intergenerationally. Top-down flows of information and technologies from research centers and buyers have reached farmers via extensionists, NGOs, and local cooperatives. Certified farmers receive more frequent and targeted visits from extensionists to ensure compliance with the code and to promote the adoption of new technologies. Certification has been a mechanism to leverage funds from donor agencies and from the Colombian government. Nevertheless, farmers bear the cost of audits and contribute to pay for the extension service through the export tax collected and managed by FNC.
Horizontal linkages among producers became stronger as farmers organized monthly meetings to share experiences, exchange practices, and gain access to resources. Intergenerational linkages have become tighter among certified farmers: their children were not only more educated than those of the noncertified ones but they also played a major role in the decision to join the certification program and in keeping records of the farm operation. Farmers, local extension agents, and FNC officials indicated that, through the process of certification, farmers came to value investing in their children's education and their participation in farm activities. These results are also consistent with similar findings in RFA-certified cocoa farms in West Africa (RFA and COSA 2012). The involvement of younger coffee growers in adopting sustainable practices cannot be underestimated. Farmers interviewed were 55 years old, on average, with only 5 years of formal education. A more educated generation of farmers, who is also more aware of environmental issues and more attuned to market demands, is perhaps the most valuable asset of the sector for the future.

Certification has produced positive feedback in upgrading, thus confirming expectations of positive impacts of voluntary standards on smallholders' ability to improve production practices and added value (Lee et al. 2012). During our fieldwork, FNC launched, in partnership with a client, a new value-added program for late harvesting coffee beans that will command a higher premium. Certified farmers were the main focus of the campaign, given their demonstrated ability to 
Fig. 4. Certified farmers' main reasons for staying in the certification program $(n=43)$.

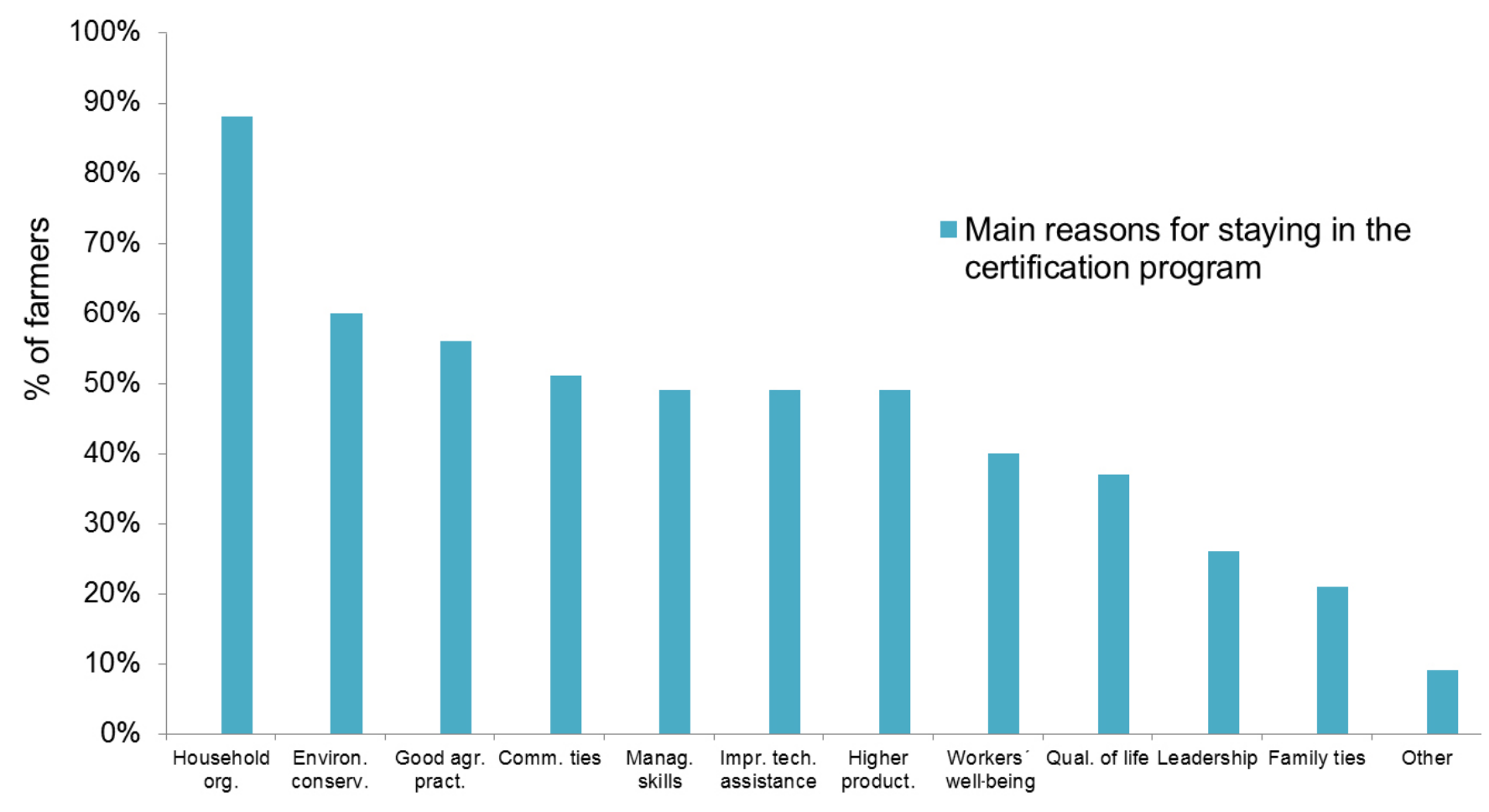

comply with standards and deliver the product with the required characteristics. With their certification experience, farmers were more confident in their decision to join this new venture. Conservation of water resources, biodiversity, and forest stands have all increased on certified farms. Although farms became more specialized in coffee, the area devoted to coffee for both certified and noncertified farmers increased by more than $40 \%$ in the last five years. The deeper connection to international markets via eco-certification is promoting the adoption of practices that are beneficial for the life support systems at the local and regional levels. Certification is producing both increased specialization (Zimmerer 2007), but also greater in-farm diversity, as well as promoting a richer, if yet more tightly woven tapestry of land uses.

Certification processes are generating spillover effects on adjacent farms and communities through emulation of practices and improved transparency and traceability. Environmentally friendly technologies, such as low-water depulping and manual control of pests and diseases, have reached certified farmers and extended to noncertified ones. Implementing the SAN code required improvements in trading practices, making cooperatives more transparent and accountable in their business deals for the benefit of certified and noncertified farmers alike. These spillover effects had been observed in other contexts, in absentia of vertical integration and contract farming (Swinnen et al. 2010).

Last, our study presents no evidence that certification is leaving behind small landholders. Analyses of certification programs elsewhere alert about the financial burden these programs might impose on farmers (Gullison 2003, Giovannucci and Ponte 2005). In the case of Colombia, FNC played a key role in leveling access to certification for small and large holders. FNC had low-cost, environmentally friendly technologies that were already in place in many farms before the adoption of certification. Thus, compliance did not require farmers to make large investments or radically change their agroecological practices. Once initial investments were carried out, the financial mechanism put in place by FNC allowed farmers to maintain the certification program without additional cost to its participants. FNC also channeled resources to help poor farmers upgrade infrastructure and equipment for waste management, pesticide application and storage, and household facilities. Finally, FNC took advantage of the group certification program created by SAN to include neighboring farms on a single certificate, reducing the costs of auditing. 


\section{CONCLUSION}

Most of the previous studies evaluating the performance of certification have focused on the direct economic benefits derived from the premium. From our analysis we conclude that price premiums are only one of many elements defining the success of certification. High premiums were a key condition for entering the certification system. They provided the initial motivation for farmers to bear the cost and invest time in learning about the protocol, changing practices, and upgrades to their infrastructure. Once in the certification program, farmers valued other gains far more than price differentials.

Nonpremium benefits explain retention in the certification program. Through certification farmers acquired skills and abilities that helped them mobilize assets and make their operation more sustainable, even in the face of decreasing premiums. Farmers gained access to information, technology, social networks, and resources that did not reach them before they became certified. Coffee growers widened their access to market outlets whose prices are more stable. They have done so while enhancing local agroecosystems.

Certification has also become a vehicle for upgrading, as farmers have entered new chains in which more value is generated. Smallholders, supported by a strong institutional arrangement that delivers technical and commercial services, have not only coped with market trends but have also creatively adapted to changing conditions in the global economy and consumer preferences in ways that are beneficial to their livelihoods, their offspring, and the environment.

Coffee certification in Colombia demonstrates that connections between local social-ecological systems and larger global forces can produce more sustainable livelihoods and land uses. Changes in individuals' behavior, of both consumers and producers, and in the institutional arrangements governing trade in agricultural commodities have the potential to increase the resilience of socialecological systems.

Responses to this article can be read online at: http://www.ecologyandsociety.org/issues/responses. php/5595

\section{Acknowledgments:}

We thank the Colombian Coffee Growers Federation (FNC) for its generous support to conduct this research. In particular, we are grateful to Luis Fernando Samper and Andrés Valencia who granted us access to the information and provided useful comments on the research proposal. We would also like to thank to Néstor Serrano, Henry Parra, and all the extensionists in Santander who provided tremendous insight for this study, supported our field work, and helped us gain the trust of many farmers who generously opened the doors of their homes to answer our questions. In the Technical Division, we would like to thank Juan Pablo Becerra and Martha Córdoba who went to great lengths to provide access to spatial data and information from SICA. Dr. Sergio Mantilla, former director of the Executive Committee in Santander, provided valuable information on the history of certification programs. We thank the Morrison Institute for Population and Resource Studies at Stanford for the financial support to conduct fieldwork.

\section{LITERATURE CITED}

Adams, W. M. 2001. Green development: environment and sustainability in the Third World. Routledge, Oxon, UK.

Adger, W. N., H. Eakin, and A. Winkels. 2009. Nested and teleconnected vulnerabilities to environmental change. Frontiers in Ecology and the Environment 7:150-157. http:// dx.doi.org/10.1890/070148

Aide, T. M., and H. R. Grau. 2004. Globalization, migration, and Latin American ecosystems. Science 305:1915-1916. http://dx.doi.org/10.1126/science.1103179

Andersson, M. S., S. J. Scherr, and S. Shames, editors. 2010. TRANSLINKS: promoting transformations by linking nature, wealth and power. Case studies: bundling agricultural products with ecosystem services. Ecoagriculture Partners, Washington, D.C., USA.

Bardhan, P. 2006. Globalization and rural poverty. World Development 34:1393-1404. http://dx.doi.org/10.1016/j. worlddev.2005.10.010

Bejarano, J. 1987. El despegue cafetero (1900-1928). Pages 173 to 207 in J. Ocampo, editor. Historia económica de Colombia. Siglo Veintiuno Editores de Colombia, Bogotá, Colombia.

Benayas, J. M. R., A. C. Newton, A. Diaz, and J. M. Bullock. 2009. Enhancement of biodiversity and ecosystem services by ecological restoration: a meta-analysis. Science 325:1121-1124. http://dx.doi.org/10.1126/science.1172460

Benin, S., M. Smale, and J. Pender. 2005. Explaining the diversity of cereal crops and varieties grown on household farms in the highlands of northern Ethiopia. Pages 78-96 in M. Smale, editor. Valuing crop biodiversity: on-farm genetic resources and economic change. CABI, Wallingford, UK.

Beuchelt, T. D., and M. Zeller. 2011. Profits and poverty: certification's troubled link for Nicaragua's organic and fairtrade coffee producers. Ecological Economics 70:1316-1324. http://dx.doi.org/10.1016/j.ecolecon.2011.01.005 
Blackman, A., and M. Naranjo. 2010. Does eco-certification have environmental benefits? Organic coffee in Costa Rica. RFF Discussion Paper 10-57, Resources for the Future, Washington, D.C., USA.

Blackman, A., and J. E. Rivera. 2010. The evidence base for environmental and socioeconomic impacts of "sustainable" certification. RFF Discussion Paper 10-10, Resources for the Future, Washington, D.C., USA. http://dx.doi.org/10.2139/ $\underline{\text { ssrn. } 1579083}$

Brookfield, H., C. Padoch, H. Parsons, and M. Stocking, editors. 2002. Cultivating biodiversity: understanding, analysing and using agricultural diversity. ITDG, Warwickshire, UK.

Dauvergne, P., and J. Lister. 2012. Big brand sustainability: governance prospects and environmental limits. Global Environmental Change 22:36-45. http://dx.doi.org/10.1016/j. gloenvcha.2011.10.007

Daviron, B., and I. Vagneron. 2011. From commoditisation to de-commoditisation ... and back again: discussing the role of sustainability standards for agricultural products. Development Policy Review 29:91-113. http://dx.doi. org/10.1111/j.1467-7679.2011.00515.x

Federación Nacional de Cafeteros de Colombia (FNC). 2010. Federacion Nacional de Cafeteros - Gerencia Tecnica Sistema de Información Cafetera SICA. Federación Nacional de Cafeteros de Colombia, Bogotá, Colombia.

Federación Nacional de Cafeteros de Colombia (FNC). 2011. Commercial Statistics. Federación Nacional de Cafeteros de Colombia, Bogotá, Colombia.

Folke, C. 2006. Resilience: the emergence of a perspective for social-ecological systems analyses. Global Environmental Change 16:253-267. http://dx.doi.org/10.1016/j.

gloenvcha.2006.04.002

Giovannucci, D., and S. Ponte. 2005. Standards as a new form of social contract? Sustainability initiatives in the coffee industry. Food Policy 30:284-301. http://dx.doi.org/10.1016/ j.foodpol.2005.05.007

Gómez, M. I., C. B. Barrett, L. E. Buck, H. De Groote, S. Ferris, H. O. Gao, E. McCullough, D. D. Miller, H. Outhred, A. N. Pell, T. Reardon, M. Retnanestri, R. Ruben, P. Struebi, J. Swinnen, M. A. Touesnard, K. Weinberger, J. D. H. Keatinge, M. B. Milstein, and R. Y. Yang. 2011. Research principles for developing country food value chains. Science 332:1154-1155. http://dx.doi.org/10.1126/science.1202543

Gullison, R. E. 2003. Does forest certification conserve biodiversity? Oryx 37:153-165. http://dx.doi.org/10.1017/ $\underline{\text { S0030605303000346 }}$
Guo, S., and M. W. Fraser. 2010. Propensity score analysis. Sage, Thousand Oaks, California, USA.

Ha, D. T., and G. Shively. 2008. Coffee boom, coffee bust and small holder response in Vietnam's central highlands. Review of Development Economics 12(2):312-326. http://dx.doi. org/10.1111/j.1467-9361.2007.00391.x

Jewell, N. P. 2004. Statistics for epidemiology. Chapman and Hall/CRC, Oxon, UK.

Kaplinsky, R. 2004. Competitions policy and the global coffee and cocoa value chains. Institute of Development Studies, Brighton, UK. [online] URL: http://www.ids.ac.uk/files/ RKaplinskycocoacoffee05.pdf

King, A. 2007. Trade and totomoxtle: livelihood strategies in the Totonacan region of Veracruz, Mexico. Agriculture and Human Values 24:29-40. http://dx.doi.org/10.1007/ s10460-006-9031-3

Lee, J., G. Gereffi, and J. Beauvais. 2010. Global value chains and agrifood standards: challenges and possibilities for smallholders in developing countries. Proceedings of the National Academy of Sciences 109:12326-12331. http://dx. doi.org/10.1073/pnas.0913714108

Lybbert, T. J., A. Aboudrare, D. Chaloud, N. Magnan, and M. Nash. 2011. Booming markets for Moroccan argan oil appear to benefit some rural households while threatening the endemic argan forest. Proceedings of the National Academy of Sciences 108:13963-13968. http://dx.doi.org/10.1073/ pnas. 1106382108

Mas, A. H., and T. V. Dietsch. 2004. Linking shade coffee certification to biodiversity conservation: butterflies and birds in Chiapas, Mexico. Ecological Applications 14:642-654. http://dx.doi.org/10.1890/02-5225

McCullough, E. B., P. L. Pingali, and K. G. Stamoulis. 2008. Small farms and the transformations of agri-food systems. Pages 3-46 in E. B. McCullough, P. L. Pingali, and K. G. Stamoulis, editors. The transformation of agri-food systems: globalization, supply chains and smallholder farmers. Food and Agriculture Organization of the United Nations and Earthscan, London, UK.

McMichael, P. 2007. Globalization and the agrarian world. Pages 216-239 in G. Ritzer, editor. The Blackwell companion to globalization. Blackwell, Malden, Massachusetts, USA.

O'Brien, K. L., and R. M. Leichenko. 2000. Double exposure: assessing the impacts of climate change within the context of economic globalization. Global Environmental Change 10:221-232. http://dx.doi.org/10.1016/S0959-3780(00)00021-2 
Parsons, J. J. 1949. Antioqueño colonization in western Colombia. University of California Press, Berkeley, California, USA.

Perez-Aleman, P. 2012. Global standards and local knowledge building: upgrading small producers in developing countries. Proceedings of the National Academy of Sciences 109:12344-12349. http://dx.doi.org/10.1073/pnas.1000968108

Perfecto, I., A. Mas, T. Dietsch, and J. Vandermeer. 2003. Conservation of biodiversity in coffee agroecosystems: a tritaxa comparison in southern Mexico. Biodiversity and Conservation 12:1239-1252. http://dx.doi.org/10.1023/ A:1023039921916

Perfecto, I., and J. Vandermeer. 2008. Biodiversity conservation in tropical agroecosystems: a new conservation paradigm. Annals of the New York Academy of Sciences 1134:173-200. http://dx.doi.org/10.1196/annals.1439.011

Ponte, S., and P. Gibbon. 2005. Quality standards, conventions and the governance of global value chains. Economy and Society 34:1-31. http://dx.doi.org/10.1080/0308514042000329315

Rainforest Alliance (RFA). 2011. The Rainforest Alliance demonstrates significant growth in 2011. Rainforest Alliance, New York, New York, USA. http://www.rainforest-alliance. org/newsroom/news/annual-growth-2011

Rainforest Alliance (RFA). 2012. The Rainforest Alliance certified TM difference: sustainable agriculture certification. The Rainforest Alliance, New York, New York, USA. http:// www.rainforest-alliance.org/sites/default/files/publication/pdf/ ag_cert_difference_en_hz_jan10.pdf

Rainforest Alliance (RFA) and Committee on Sustainability Assessment (COSA). 2012. Evaluating the results of our work: the Rainforest Alliance certification on cocoa farms in Côte d'Ivoire. Rainforest Alliance, New York, New York, USA. [online] URL: http://www.rainforest-alliance.org/sites/default/ files/publication/pdf/ra-certification-cocoa-cote-divoire-cosa. pdf

Reardon, T., K. Stamoulis, and P. Pingali. 2007. Rural nonfarm employment in developing countries in an era of globalization. Agricultural Economics 37:173-183. http://dx.doi.org/10.1111/ j.1574-0862.2007.00243.X

Reina, M., G. Silva, L. F. Samper, and M. d. P. Fernandez. 2008. Juan Valdez: strategy behind the brand. Ediciones B, Bogotá, Colombia.

Rosenbaum, P. R., and D. B. Rubin. 1983. The central role of the propensity score in observational studies for causal effects. Biometrika 70:41-55. http://dx.doi.org/10.1093/biomet/70.1.41

Rueda, X., and E. F. Lambin. 2013. Linking globalization to local land uses: how eco-consumers and gourmands are changing the Colombian coffee landscapes. World
Development 41:286-301. http://dx.doi.org/10.1016/j. worlddev.2012.05.018

Scientific and Technical Advisory Panel (STAP). 2010. Environmental certification and the Global Environmental Facility: a STAP advisory document. Global Environmental Facility, Washington, D.C., USA. [online] URL: http://www. thegef.org/gef/sites/thegef.org/files/documents/C.39.Inf_.15\% 20STAP\%20-\%20Environmental\%20Certification.pdf

Sobel, M. E. 2005. Discussion: 'the scientific model of causality.' Sociological Methodology 35:99-133. http://dx. doi.org/10.1111/j.0081-1750.2006.00165.x

Sustainable Agriculture Network (SAN). 2010. Sustainable Agriculture Standards. Sustainable Agriculture Network, San José, Costa Rica. [online] URL: http://sanstandards.org/ userfiles/SAN-S-1-1\%20SAN\%20Sustainable\%20Agriculture\% 20Standard\%20July\%202010\%20v2.pdf

Swinnen, J. F. M., A. Vandeplas, and M. Maertens. 2010. Liberalization, endogenous institutions, and growth: a comparative analysis of agricultural reforms in Africa, Asia, and Europe. World Bank Economic Review 24:412-445. http:// dx.doi.org/10.1093/wber/lhq017

Tangley, L. 1996. A brewing controversy over bird-friendly coffee. Science 274:1300. http://dx.doi.org/10.1126/ science.274.5291.1300

Tejeda-Cruz, C., E. Silva-Rivera, J. R. Barton, and W. J. Sutherland. 2010. Why shade coffee does not guarantee biodiversity conservation. Ecology and Society 15(1): 13. [online] URL: http://www.ecologyandsociety.org/vol15/iss1/ $\underline{\operatorname{art} 13 /}$

United States Department of Agriculture (USDA). 2011. Production, supply and distribution online. United States Department of Agriculture, Foreign Agricultural Service, Washington, D.C., USA. [online] URL: http://www.fas.usda. gov/psdonline/

van Kuijk, M., F. E. Putz, and R. Zagt. 2009. Effects offorest certification on biodiversity. Tropenbos International, Wageningen, Netherlands. [online] URL: http://www. tropenbos.org/publications/effects+of+forest+certification+on+ biodiversity.

van Vliet, N., O. Mertz, A. Heinimann, T. Langanke, U. Pascual, B. Schmook, C. Adams, D. Schmidt-Vogt, P. Messerli, S. Leisz, J.-C. Castella, L. Jorgensen, T. BirchThomsen, C. Hett, T. Bech-Bruun, A. Ickowitz, K. C. Vu, K. Yasuyuki, J. Fox, C. Padoch, W. Dressler, and A. D. Ziegler. 2012. Trends, drivers and impacts of changes in swidden cultivation in tropical forest-agriculture frontiers: a global assessment. Global Environmental Change 22:418-429. http://dx.doi.org/10.1016/j.gloenvcha.2011.10.009 
Winship, C., and R. D. Mare. 1992. Models for sample selection bias. Annual Review of Sociology 18:327-350. http:// dx.doi.org/10.1146/annurev.so.18.080192.001551

Young, O. R., F. Berkhout, G. C. Gallopin, M. A. Janssen, E. Ostrom, and S. van der Leeuw. 2006. The globalization of socio-ecological systems: an agenda for scientific research. Global Environmental Change 16:304-316. http://dx.doi. org/10.1016/j.gloenvcha.2006.03.004

Zimmerer, K. S. 2007. Agriculture, livelihoods, and globalization: the analysis of new trajectories (and avoidance of just-so stories) of human-environment change and conservation. Agriculture and Human Values 24:9-16. http:// dx.doi.org/10.1007/s10460-006-9028-y

Zimmerer, K. S. 2010. Biological diversity in agriculture and global change. Annual Review of Environment and Resources 35:137-166. http://dx.doi.org/10.1146/annurev- 